\title{
Güvenli Çalışma Ortamları İçin Radyasyon Riskinin Değerlendirilmesi
}

\section{Evaluation of Radiation Risk for Safe Working Environments}

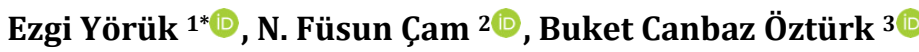 \\ 1, Ege Üniversitesi Fen Bilimleri Enstitüsü İş Güvenliği Bölümü, İzmir, TÜRKiYE \\ ${ }^{2,3}$ Ege Üniversitesi Fen Fakültesi Fizik Bölümü, İzmir, TÜRKIYE \\ Sorumlu Yazar / Corresponding Author* : ezgiikrnz@gmail.com
}

Geliş Tarihi / Received: 26.12..2019

Araștırma Makalesi/Research Article

Kabul Tarihi / Accepted: 27.12.2020

DOI:10.21205/deufmd 2021236802

Atıf șekli/How to cite: YÖRÜK E., CAM N. F., CANBAZ ÖZTÜRK B. (2021). Güvenli Çalışma Ortamları İçin Radyasyon Riskinin

Değerlendirilmesi. DEUFMD, 23(68), 357-367.

\section{$\ddot{0} \mathbf{z}$}

Son yıllarda ofislerde meydana gelen meslek hastalıklarının artması ofis ortamı risk etmenlerinin daha detaylı araştırılması, incelenmesi gerekliliğini ortaya koymuştur. Ofis ortamı, az tehlikeli işler sınıfında değerlendirilse de uzun vadede yarattığı dramatik sonuçlar yönünden ofis ortamındaki/bina içi ortamdaki radyasyon riski değerlendirilmelidir. Bu kapsamda sunulan "Güvenli Çalışma Ortamları için Radyasyon Riskinin Değerlendirilmesi" başlıklı bu çalışmada, Ege Üniversitesi kampüsünde öğrenci yoğunluğunun çok olduğu kütüphane, laboratuvar vb. alanlarda iyonlaştırıcı radyasyon kaynağı radon ve iyonlaștırıcı olmayan radyasyon (EMA) ölçümleri yapılarak, sonuçlar ulusal ve uluslararası sınır değerler ile karşılaştırılmış, çalışma alanlarının İş Sağlığı ve Güvenliği yönünden uygunluğu değerlendirilmiştir.

Anahtar kelimeler: Radon gazı, elektromanyetik alan, radyasyon, güvenli çalışma ortamları

\begin{abstract}
Increase on occupational diseases which has occurred in offices during recent years, reveals the necessity of risk factors on office environment should be researched and investigated in a broader scale. Even though, the office / indoor environment is considered within the low risk works, radiation risk in office / indoor environment should be evaluated more, because of its dramatic outcomes which it creates in long term. In this study which is entitled as " Evaluation of Radiation Risk for Safe Working Environments" which presented within that context, by making measurements of non-ionizing radiation (EMA) and ionizing radiation source radon, in areas such as library, laboratory and etc. where the student density is so high in Ege University campus and the results have been compared with the national and international limit values, to see its convenience of working areas have been evaluated in terms of Occupational Health and Safety.
\end{abstract}

Keywords: Radon gas, electromagnetic field, radiation, safe working environments 


\section{Giriş}

Teknolojinin gelişmesinin bir sonucu olarak, günümüzde kapalı ortam ve ofis çalışanlarında gözlemlenen sağlık problemlerinin artması, bu alandaki araştırmalara daha çok önem verilmesini gerektirmiş ve yaşanan sağlık problemleri meslek hastalığı gruplarında yer almıştır. Kapalı ortamlarda gözlemlenen rahatsızlıkların çoğu fiziksel risk etmenlerinden kaynaklanır ve en önemlilerinden biri radyasyona dayalı hastalıklardır.

Ofis ortamlarında maruz kalınabilecek radyasyon kaynakları iyonize olan ve iyonize olmayan radyasyon kaynakları olarak iki başlık altında incelenebilir. İyonize radyasyon kaynaklarından olan radon (Rn-222) gaz formunda olup, doğal bir radyasyon kaynağıdır. Jeolojik kökenli uranyumun bozunması sonucu açığa çıkan Rn gazı, bina içlerine nüfuz ederek kapalı alanlarda birikir ve yüksek konsantrasyon seviyelerine ulașabilir. Rn konsantrasyon seviyesinin yüksek olması, insan sağlığını önemli derecede olumsuz etkiler [1][2].

Rn gazı ölçümleri ilk olarak 1956 yılında İsveç’ te evlerde ve binalarda yapılmıștır. Ölçümler sonucunda bazı binalarda Rn gazı konsantrasyon seviyeleri çok yüksek bulunmuştur. Her ne kadar o bölgede istisnai bir durum olduğu düșünülse de bu, pek çok bölgede incelemeler ve çalışmalar yapılması için bir başlangıç olmuştur [3].

Madenciler üzerine yapılan ilk çalışma Alman fizikçi Georgius Agricola (1494-1555) tarafından yapılmış ve 1556 yılında "Madenler Üzerine" (De Re Metallica) adlı kitabı yayınlanmıștır [4]. Madenlerde yapılan araştırmalara pek çok örnek verilebilir. Olszewski ve Arkadașları (2005), Polonya'da bulunan Eski Kowary uranyum madeninde ve Südetler yakınında bulunan kapalı uranyum madenlerinde çalıșma yapmıșlar ve bu madenlerdeki ortalama radon konsantrasyon değerlerini $\quad 400-2000 \quad \mathrm{~Bq} / \mathrm{m}^{3}$ aralığında ölçmüşlerdir [5]. Avrupa'da, Türkiye'de ve ICRP'nin kabul ettiği sınır değerin $1000 \mathrm{~Bq} / \mathrm{m}^{3}$ olduğu göz önüne alındığında, bu değerlerin yüksek olduğu görülmektedir. Sık havalandırılmayan, kapalı binalarda da ölçülen radon konsantrasyon seviyelerinin insan sağlığını tehlikeye sokan seviyelere ulaşabildiği yapılan çalıșmalarla kanıtlanmıștır [6]. Maden ocakları dışında, metro, tünel, mağaralar, radon kaplıcaları gibi yerler ile fabrikalar, alıșveriş merkezleri, okul ve ofisler de radon riski tașıyan isyerleri olarak tanımlanabilmektedir [7]. Vücuda solunum yoluyla giren radon gazı alfa ıșıması yaparak DNA yapısını bozar. Radon gazına sürekli ve yoğun bir şekilde maruz kalınması sonucu ise tümör oluşur ve özellikle akciğer kanserine neden olur [8][9].

Ayrıca, kapalı ortamlarda iç ortam hava kalitesini etkileyen kirletici gazlar $\left(\mathrm{CO}_{2}, \mathrm{CO}, \mathrm{NO}_{2}\right.$, $\mathrm{O}_{3}, \mathrm{SO}_{2}$, formaldehit ve radon) baş dönmesi ve baş ağrısı, boğazda ve gözlerde tahriş ve yanma, öksürme, hapşırma, yorgunluk, mide bulantısı, ciltte tahriş ve yanma gibi semptomları olan Hasta Bina Sendromu'na neden olmaktadır [10].

Son yıllarda dünyada pek çok ülkede araştırmalar yapılmakta ve Rn-222'nin insan sağlığı üzerindeki zararlı etkileri üzerine çalışılmaktadır. ICRP (Uluslararası Radyasyondan Korunma Komitesi), WHO, UNSCEAR (Birleșmiș Milletler Atomik Radyasyonun Etkileri Bilimsel Komitesi) ve TAEK (Türkiye Atom Enerjisi Kurumu) gibi pek çok kuruluş bu konu üzerinde çalışmakta ve insanların sağlığı için sınır konsantrasyon değerleri tavsiye etmektedir. ICRP ve TAEK gibi kuruluşlar kapalı binalarda Rn limit değerini 400 $\mathrm{Bq} / \mathrm{m}^{3}$ olarak belirlemiştir [11][12]. WHO ve UNSCEAR ise $\mathrm{Rn}$ konsantrasyonu limit değerinin, $100 \mathrm{~Bq} / \mathrm{m}^{3}$ değerini aşmaması gerektiğini belirtmiştir [13]. Ülkemizde 24/03/2000 tarihli ve 23999 sayılı Resmî Gazete'de yayımlanan Radyasyon Güvenliği Yönetmeliği'nin 29/09/2004 tarih ve 25598 sayılı Resmî Gazete'de yayımlanan Radyasyon Güvenliği Yönetmeliğinde Değişiklik Yapılmasına Dair Yönetmelik ile değiștirilen 37 'nci maddesine göre evlerde radon seviyesi $400 \mathrm{~Bq} / \mathrm{m}^{3}$ 'ü, işyerlerindeki radon seviyesi 1000 $\mathrm{Bq} / \mathrm{m}^{3}$ 'ü aşmamalıdır [14].

İyonize olmayan radyasyonlara ise günlük hayatımızda da çok sık maruz kaldığımız elektromanyetik alanlar (EMA) örnek olarak verilebilir. İçerisinden elektrik akımı geçen tüm cihazların ortama elektromanyetik alan yaydığ bilinmektedir. Özellikle ofis çalıșanlarının, uzun çalışma saatleri boyunca cep telefonları, bilgisayar vb. cihazların neden oldukları elektromanyetik alanlara maruz kaldıkları, yapılan çalışmalarla ortaya konmuştur.

Wertheimer ve Leeper'in (1979) elektromanyetik alanın biyolojik etkileri üzerine yapmış olduğu bir çalışmada elektromanyetik 
alan maruziyeti ile çocukluk çağı kanserleri arasındaki ilișki incelenmiștir [15]. Üreme sağlığı, sinir dokusunun bozulması ve kalp rahatsızlıkları gibi çok daha ciddi hastalıklara neden olabildiğine dikkat çekilen bu çalışmadan sonra konuyla ilgili araştırmaların artış gösterdiği görülmektedir [15].

Yakıncı (2016) yılında yayınladığı çalışmasında EMA'nın insan sağlığı üzerindeki etkilerini incelemiştir. Elektromanyetik kirlilik, insan üzerinde baş ağrısı, baş dönmesi, yorgunluk, genel keyifsizlik, kalp ritminde ve kan dolașımında değișiklik, hafıza kaybı, boyunda sertlik, sindirim ve dolașım sorunları gibi pek çok sağlığı tehlikeye sokan sorunlara neden olmaktadır. Aynı zamanda yapılan araștırmalar EMA'nın beyinden hücrelere gönderilen sinyallere engel olarak, vücudun bağışılklık sistemine de zarar verdiğini göstermektedir [16].

Elektromanyetik alanların etkileri üzerine çalışmalar yapan Dünya Sağlık Örgütü (WHO), Dünya Çalıșma Örgütü (ILO) ve Uluslararası İyonlaştırıcı Olmayan Radyasyondan Korunma Komisyonu (ICNIRP) gibi kuruluşlar, elektromanyetik alanlar için sınır değerleri tavsiye etmiştir. ICNIRP'nin tavsiye ettiği sınır değerler, $900 \mathrm{MHz}$ için 41,25 V/m iken, $1800 \mathrm{MHz}$ için 58,33 V/m şeklindedir [17].

Modern hayatta insanlar zamanlarının çoğunu evleri haricinde iş yerleri ve ofisler gibi kapalı ortamlarda geçirdiklerinden dolayı tavsiye edilen sınır değerler önem kazanmaktadır. Günün en az 8 saatinin geçirildiği bu alanlarda, diğer fiziksel risk etmenleri gibi doğrudan gözle görülmeyen ve etkileri hemen ortaya çlkmadığı için radon gazı ile iyonlaştırıcı olmayan elektromanyetik alan (EMA) radyasyonları göz ardı edilmekte olup gereken önem verilmemektedir. Bu anlamda "Güvenli Çalışma Ortamları için Radyasyon Riskinin Değerlendirilmesi" konulu bu çalıșmada insan sağlığını önemli derecede olumsuz etkileyen nem, basınç ve sıcaklık değişimleri ile radon gazı ve EMA ölçümlerinin yapılması, risk düzeylerinin belirlenmesi sonuçların ulusal ve uluslararası sınır değerlerle karşılaştırılarak Ege Üniversitesi kampüsünde seçilen laboratuvar, derslik, kafeterya ve kütüphane gibi kapalı çalışma alanlarının iş sağlığı ve güvenliğ yönünden uygunluğunun değerlendirilmesi hedeflenmiştir.

\section{Materyal ve Metot}

Kapalı çalıșma ortamları için insan sağlığını olumsuz etkileyen iyonlaştırıcı (radon) ve iyonlaştırıcı olmayan (elektromanyetik alan) ölçümlerin yapılarak risk düzeylerinin belirlendiği, sonuçların ulusal ve uluslararası sınır değerler ile karşılaștırıldığı ve radyasyon güvenliğini araştırmayı amaçlayan bu çalışmada, Ege Üniversitesi içerisindeki çalıșan ve öğrenci yoğunluğunun çok olduğu 4 istasyon belirlenmiştir. Bina içindeki konum olarak özelliklerinin farklı olduğu ve öğrencilerin yoğun olarak bulundukları bu istasyonlar, Merkez Kütüphane, Bilgisayar Laboratuvarı, Öğrenci Kafeteryası ve zemin katta seçilen bir amfi derslik olarak belirlenmiştir.

\subsection{Radon Ölçümü}

Çalıșma alanı olarak belirlenen 4 istasyonda 8 ay boyunca periyodik $\mathrm{Rn}$ ölçümleri yapılmıştır. Radon ölçümleri ile eş zamanlı olarak nem, basınç ve sıcaklık değişimleri de kaydedilmiştir. Çalışmada Corentium Plus Rn gazı ölçüm cihazı kullanılmıștır. Tüm ölçümler zeminden $1,5 \mathrm{~m}$ yükseklikte ve gündüz saatlerinde çalışanların ofislerinde bulunduğu zaman dilimi içerisinde ve boş olduğu zamanlarda yapılmıştır. Şekil 2.1'de Mart 2018 dönemi için Bilgisayar Laboratuvarı'nda alınan Rn gazı, nem, basınç ve sıcaklık değişimleri örnek olarak sunulmuştur.

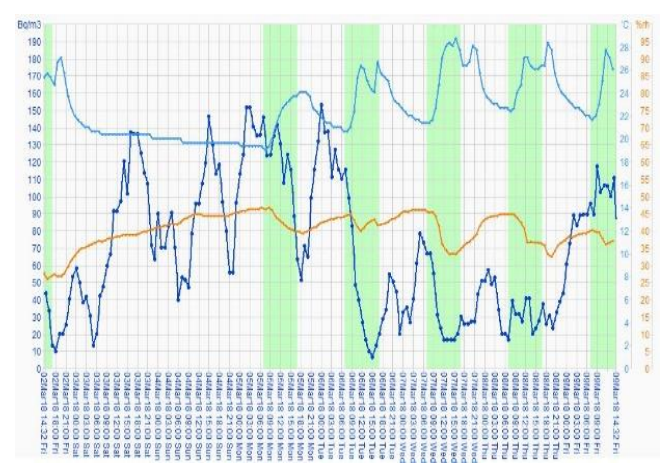

Şekil 2.1 Mart 2018 Bilgisayar Laboratuvarı Rn gazı konsantrasyonlarının haftalık değișimi.

2.2. Bina içi Rn-222 Kaynaklı Yıllık Etkin Doz Tahminleri

Ölçülen ortalama Rn konsantrasyon değerleri kullanılarak, kișinin Rn'a maruz kalma sonucu alacağı yıllık etkin doz eșdeğeri (YEDE), Rn maruziyetinin belirlenmesi açısından önemlidir.

Ylllık etkin doz eşdeğeri YEDE, 


$$
\mathrm{YEDE}=\mathrm{C}(\mathrm{Rn}) \times \mathrm{F} \times \mathrm{D} \times \mathrm{t}
$$

bağıntısı kullanılarak UNSCEAR 2000 raporuna göre hesaplanmıștır [18].

Bu bağıntıda,

$\mathrm{C}(\mathrm{Rn})$ : Radon konsantrasyonu (Bq/ $\left.\mathrm{m}^{3}\right)$,

F: Radon ile bozunma ürünleri arasındaki denge faktörü,

D: Doz dönüşüm katsayısı,

$\mathrm{t}_{1}$ : Bina içerisinde bir yılda ortalama geçirilen zaman (saat) - (Tüm gün için - \%100)

$\mathrm{t}_{2:}$ Bina içerisinde bir yılda ortalama geçirilen zaman (saat) - (Çalışma saatleri için - \%33)

olup, denge faktörü 0,4 ; doz dönüșüm katsayısı ise $9 \times 10^{-9}(\mathrm{~Sv} / \mathrm{saat}) /\left(\mathrm{Bq} / \mathrm{m}^{3}\right)$ olarak alınmıștır. Hesaplamalar tüm gün (24 saat) için ve çalışma saatleri (8 saat) için yapılmıștır.

\subsection{Elektromanyetik Alan Ölçümü}

Çalışmada, söz konusu 4 istasyonda 3,5 GHz'e kadar ölçüm yapabilen PCE-EM 29 cihazı kullanılarak EMA ölçümleri yapılmıștır. Anlık ortam ölçümü alınan bu çalışmada, Aralık 2017 tarihinden başlanarak haftada 1 gün ve sabah, öğlen ve öğleden sonra olmak üzere 3'er ölçüm alınmıştır. Ölçümler 8 ay boyunca alınmış ve Temmuz 2018 tarihinde sonlandırılmıstır. Her bir istasyon için ayda 12 ölçüm olmak üzere toplamda 96 ölçüm alınmıștır.

\section{Bulgular}

\subsection{Radon Gazı}

Ege Üniversitesi içerisinde, öğrenci yoğunluğunun çok olduğu 4 istasyon Merkez Kütüphane, Bilgisayar Laboratuvarı, zemin katta bir Amfi ve Öğrenci Kafeteryası olarak belirlenmiştir. Belirlenen 4 istasyonda alınan Rn-222 ölçüm sonuçlarının tanımlayıcı istatistikleri Tablo 3.1, Tablo 3.2, Tablo 3.3 ve Tablo 3.4'te verildiği gibidir.

Tanımlayıcı istatistik sonuçlarında skewness ve kurtosis değerlerinin sıfıra yakın olması ile aritmetik ortalama, medyan ve geometrik ortalama değerlerinin karşılaştırılması ölçüm sonuçlarının frekans dağılımları hakkında bilgi vermektedir. Normal dağılım fonksiyonunda, aritmetik ortalama ile medyan değeri benzer iken, log-normal dağılım fonksiyonunda geometrik ortalama ile medyan değeri birbirine benzer olmaktadır. Tanımlayıcl istatistiğin desteklenmesi için ise her bir değișkene parametrik olmayan Kolmogorov-Smirnov normalite testi uygulanmıștır. Bu test sonucu elde edilen anlamlılık (significance) değerlerinin istatistiksel hesaplamalarda sınır değeri kabul edilen 0,05 'ten büyük olması dağılımların normal olduğunu göstermektedir [19][20].

Tablo 3.1'de verildiği gibi, kütüphane için tam zamanlı ölçülen Rn konsantrasyonlarının aritmetik ortalaması $16,9 \pm 4,3 \quad \mathrm{~Bq} / \mathrm{m}^{3}$ tür. Çalışma saatleri için ortalama radon konsantrasyon seviyesi $18,2 \pm 4,9 \mathrm{~Bq} / \mathrm{m}^{3}$ olarak bulunmuștur. Tam zamanlı ve çalıșma sürelerine ait tanımlayıcı istatistik sonuçlarına göre frekans dağılımının normal dağılıma uymadığı görülmüștür. Frekans dağılımının normal dağılıma uymadığı durumlarda dağılımı medyan değeri ile temsil etmek daha anlamlı olmaktadır. Bu doğrultuda, tam zamanlı ve çalışma saatleri için radon konsantrasyonlarının medyan değerleri kütüphane için sırasıyla $10,3 \mathrm{~Bq} / \mathrm{m}^{3}$ ve 10,6 Bq/m $\mathrm{m}^{3}$ olarak bulunmuştur. Merkez Kütüphane, öğrenci giriş çıkışlarının çok yoğun olduğu, vize ve final sinavları döneminde 24 saat açık olan bir binadır. Ölçümlerin zemin katta gerçekleştirilmesi nedeniyle Rn konsantrasyonlarının yüksek çlkabileceği düşünülse de, giriş-çıkış yoğunluğunun fazla olmasından dolayı binanın hava sirkülasyonu oldukça artmış ve radon konsantrasyonları çok yüksek seviyelere ulaşmamıştır.

Tablo 3.2.'de verilen Bilgisayar Laboratuvarı radon konsantrasyonlarına ait tanımlayıcl istatistik sonuçlarına göre tam zamanlı ölçümler için ortalama $121,3 \pm 7,3 \mathrm{~Bq} / \mathrm{m}^{3}$, çalışma saatleri için ise $124,9 \pm 8,1 \mathrm{~Bq} / \mathrm{m}^{3}$ olarak bulunmuștur. Frekans dağılımı normal dağılıma uymaktadır. Merkez Kütüphane'ye göre çok yüksek ortalama değerler bulunmasının nedeni olarak, Bilgisayar Laboratuvarı'nın eski bir bina içerisinde olması ve zemin katta yer alması düșünülebilir. Aynı zamanda Bilgisayar Laboratuvarı Merkez Kütüphane'ye ve Öğrenci Kafeteryasına göre az kullanılmasından dolayı fazla havalandırılamamakta ve radon gazı birikerek yüksek seviyelere çlkabilmektedir.

Bir diğer istasyon olan Öğrenci Kafeteryası'nda Rn-222 ölçüm sonuçları tam zamanlı ölçümler için ortalama $50,6 \pm 3,8 \mathrm{~Bq} / \mathrm{m}^{3}$ ve çalışma saatleri için ise ortalama değer $33,5 \pm 4,9 \mathrm{~Bq} / \mathrm{m}^{3}$ olarak bulunmuş ve Tablo 3.3 'te verilmiştir. Çalışma saatleri için alınan ölçümlerin normal dağılıma uymadığı görülmektedir. Çalıșma saatleri için 
radon konsantrasyonlarının medyan değeri 19,6 $\mathrm{Bq} / \mathrm{m}^{3}$ olarak bulunmuștur. Öğrenci Kafeteryası da zemin katta yer almakta fakat 3 ayrı kapısının bulunması ve bu kapıların gün içinde sıklıkla açık tutulması, sürekli bir hava sirkülasyonu oluşturmakta, bu da radon konsantrasyon seviyesinin düşmesine neden olmaktadır.

Son istasyon olan amfi derslikte ise alınan ölçümlerin tanımlayıcı istatistikleri Tablo 3.4'te verildiği gibidir. Tam zamanlı ölçümler için ortalama radon konsantrasyon seviyesi $268,3 \pm 27,4 \mathrm{~Bq} / \mathrm{m}^{3}$ ve çalışma saatleri aralığında ise ortalama değer $264,5 \pm 27,8 \mathrm{~Bq} / \mathrm{m}^{3}$ olarak bulunmuştur. Burada ise tam zamanlı ölçüm sonuçlarına göre frekans dağılımı normal dağılıma uymamaktadır. Tam zamanlı olarak alınan ölçümlere göre medyan değerinin 260,4 $\mathrm{Bq} / \mathrm{m}^{3}$ olduğu görülmektedir. Amfide ölçülen radon konsantrasyon değerleri diğer istasyonlara göre daha yüksektir.

Amfinin zemin katta ve yerin altına doğru inen bir salon olması, çok sık ders işlenmemesinden kaynaklı olarak kapalı kalmasından dolayı sık havalandırılmaması ölçülen bu yüksek değerlerin başlıca nedenleridir.

Tablo 3.1. Kütüphane Rn gazı konsantrasyonlarına ait tanımlayıcı istatistik

\begin{tabular}{|c|c|c|c|c|c|}
\hline & $\begin{array}{c}\text { Rn } \\
\text { Konsantrasyonu } \\
\left(\mathrm{Bq} / \mathrm{m}^{3}\right)\end{array}$ & $\begin{array}{c}\text { Çalışma Saatleri } \\
\text { Rn } \\
\text { Konsantrasyonu } \\
\left(\mathrm{Bq} / \mathrm{m}^{3}\right)\end{array}$ & $\begin{array}{l}\text { Sicaklık } \\
\left({ }^{\circ} \mathrm{C}\right)\end{array}$ & $\begin{array}{l}\text { Nem } \\
(\% \mathrm{RH})\end{array}$ & $\begin{array}{l}\text { Basınç } \\
\text { (mbar) }\end{array}$ \\
\hline Ölçüm Sayısı & 66 & 66 & 66 & 66 & 66 \\
\hline $\begin{array}{c}\text { Aritmetik Ortalama } \pm \\
\text { SH } \\
\end{array}$ & $16,9 \pm 4,3$ & $18,2 \pm 4,9$ & $22,7 \pm 0,2$ & $40,1 \pm 1,5$ & $1008,8 \pm 0,9$ \\
\hline Geometrik Ortalama & 10,8 & 10,3 & 22,6 & 38,2 & 1008,7 \\
\hline Standart Sapma (SD) & 34,6 & 39,7 & 1,7 & 12,0 & 7,0 \\
\hline Min. & 2,5 & 2,5 & 19,9 & 15,6 & 994,8 \\
\hline 25' inci Yüzdelik & 7,9 & 5,4 & 21,6 & 31 & 1003,5 \\
\hline Medyan & 10,3 & 10,6 & 22,3 & 38,9 & 1007,8 \\
\hline 75' inci Yüzdelik & 15,6 & 16,8 & 23,9 & 48,1 & 1013,6 \\
\hline Max. & 271,2 & 311 & 28,8 & 65 & 1023,9 \\
\hline Skewness & 6,6 & 6,6 & 1,1 & 0,2 & 0,3 \\
\hline Kurtosis & 47 & 47,2 & 1,8 & $-0,7$ & $-0,4$ \\
\hline $\begin{array}{c}\text { Kolmogorov-Smirnov } \\
\text { Test Sig. } \\
\end{array}$ & 0,00 & 0,00 & 0,20 & 0,70 & 0,70 \\
\hline Frekans Dağılımı & Log-normal & Log-normal & Normal & Normal & Normal \\
\hline
\end{tabular}


DEÜ FMD 23(68), 357-367, 2021

Tablo 3.2. Bilgisayar Laboratuvarı Rn gazı konsantrasyonlarına ait tanımlayıcı istatistik

\begin{tabular}{|c|c|c|c|c|c|}
\hline & $\begin{array}{c}\text { Rn } \\
\text { Konsantrasyonu } \\
\left(\mathrm{Bq} / \mathbf{m}^{3}\right)\end{array}$ & $\begin{array}{c}\text { Çalışma Saatleri } \\
\text { Rn } \\
\text { Konsantrasyonu } \\
\left(\mathrm{Bq} / \mathrm{m}^{3}\right)\end{array}$ & $\begin{array}{c}\text { Sicaklık } \\
\left({ }^{\circ} \mathrm{C}\right)\end{array}$ & $\begin{array}{l}\text { Nem } \\
(\% \text { RH) }\end{array}$ & $\begin{array}{l}\text { Basınç } \\
\text { (mbar) }\end{array}$ \\
\hline Ölçüm Sayısı & 64 & 64 & 64 & 64 & 64 \\
\hline $\begin{array}{c}\text { Aritmetik Ortalama } \pm \\
\text { SH }\end{array}$ & $121,3 \pm 7,3$ & $124,9 \pm 8,1$ & $22,5 \pm 0,3$ & $41,8 \pm 0,7$ & $1008,9 \pm 0,9$ \\
\hline Geometrik Ortalama & 104,6 & 99,9 & 22,4 & 41,3 & 1008,9 \\
\hline Standart Sapma (SD) & 58,1 & 64,8 & 2,2 & 5,9 & 6,3 \\
\hline Min. & 17,2 & 2,5 & 17,3 & 26,9 & 1000,3 \\
\hline 25'inci Yüzdelik & 82,6 & 79,4 & 20,9 & 38,4 & 1004,3 \\
\hline Medyan & 119,3 & 124,2 & 22,6 & 41 & 1007,3 \\
\hline 75'inci Yüzdelik & 157,3 & 167,4 & 24,2 & 46,7 & 1014,2 \\
\hline Max. & 267 & 261,7 & 26,1 & 52,7 & 1025,3 \\
\hline Skewness & 0,3 & 0,1 & $-0,3$ & $-0,3$ & 0,7 \\
\hline Kurtosis & $-0,5$ & $-0,7$ & $-0,7$ & $-0,2$ & $-0,2$ \\
\hline $\begin{array}{c}\text { Kolmogorov-Smirnov } \\
\text { Test Sig. }\end{array}$ & 0,89 & 0,98 & 0,83 & 0,89 & 0,19 \\
\hline Frekans Dağılımı & Normal & Normal & Normal & Normal & Normal \\
\hline
\end{tabular}

Tablo 3.3. Kafeterya Rn gazı konsantrasyonlarına ait tanımlayıcı istatistik

\begin{tabular}{|c|c|c|c|c|c|}
\hline & $\begin{array}{c}\mathbf{R n} \\
\text { Konsantrasyonu } \\
\left(\mathrm{Bq} / \mathbf{m}^{3}\right)\end{array}$ & $\begin{array}{l}\text { Çalışma Saatleri } \\
\text { Rn } \\
\text { Konsantrasyonu } \\
\left(\mathrm{Bq} / \mathrm{m}^{3}\right)\end{array}$ & $\begin{array}{c}\text { Sicaklık } \\
\left({ }^{\circ} \mathrm{C}\right)\end{array}$ & $\begin{array}{c}\text { Nem } \\
\text { (\%RH) }\end{array}$ & $\begin{array}{l}\text { Basınç } \\
\text { (mbar) }\end{array}$ \\
\hline Ölçüm Sayısı & 64 & 64 & 64 & 64 & 64 \\
\hline $\begin{array}{c}\text { Aritmetik Ortalama } \pm \\
\text { SH }\end{array}$ & $50,6 \pm 3,8$ & $33,5 \pm 4,9$ & $24,5 \pm 0,7$ & $44,5 \pm 0,8$ & $1006,7 \pm 0,6$ \\
\hline Geometrik Ortalama & 31,1 & 19,0 & 23,8 & 44,1 & 1006,6 \\
\hline Standart Sapma (SD) & 5,1 & 39,6 & 5,6 & 6,1 & 5,1 \\
\hline Min. & 5,1 & 2,5 & 17 & 30,5 & 996,8 \\
\hline 25' inci Yüzdelik & 29,3 & 9,3 & 18,9 & 40,3 & 1002,9 \\
\hline Medyan & 43,2 & 19,6 & 23,5 & 44,9 & 1006 \\
\hline 75' inci Yüzdelik & 67,9 & 39,9 & 30,2 & 48,2 & 1009,8 \\
\hline Max. & 155,7 & 170,5 & 34 & 57,7 & 1021 \\
\hline Skewness & 1,1 & 1,9 & 0,2 & 0 & 0,6 \\
\hline Kurtosis & 1,8 & 3,4 & $-1,5$ & $-0,2$ & 0,7 \\
\hline $\begin{array}{c}\text { Kolmogorov-Smirnov } \\
\text { Test Sig. }\end{array}$ & 0,40 & 0,00 & 0,10 & 0,50 & 0,60 \\
\hline Frekans Dağılımı & Normal & Log-normal & Normal & Normal & Normal \\
\hline
\end{tabular}


DEÜ FMD 23(68), 357-367, 2021

Tablo 3.4. Amfi Rn gazı konsantrasyonları için tanımlayıcı istatistik

\begin{tabular}{|c|c|c|c|c|c|}
\hline & $\begin{array}{c}\text { Rn } \\
\text { Konsantrasyon } \\
\text { u }\left(\mathrm{Bq} / \mathrm{m}^{3}\right)\end{array}$ & $\begin{array}{c}\text { Çalışma } \\
\text { Saatleri Rn } \\
\text { Konsantrasyon } \\
\left.\text { u (Bq/m } / \mathbf{m}^{3}\right)\end{array}$ & $\begin{array}{c}\text { Sicaklık } \\
\left({ }^{\circ} \mathrm{C}\right)\end{array}$ & $\begin{array}{l}\text { Nem } \\
(\% R H)\end{array}$ & $\begin{array}{l}\text { Basınç } \\
\text { (mbar) }\end{array}$ \\
\hline Ölçüm Sayısı & 62 & 62 & 62 & 62 & 62 \\
\hline $\begin{array}{c}\text { Aritmetik Ortalama } \\
\pm \mathrm{SH} \\
\end{array}$ & $268,3 \pm 27,4$ & $264,5 \pm 27,8$ & $20,5 \pm 0,4$ & $52,5 \pm 0,9$ & $1007,4 \pm 0,7$ \\
\hline Geometrik Ortalama & 246,5 & 141,7 & 19,3 & 51,9 & 1007,4 \\
\hline Standart Sapma (SD) & 215,9 & 219 & 2,8 & 7,4 & 5,7 \\
\hline Min. & 7,5 & 6,2 & 15,9 & 34,5 & 993,8 \\
\hline 25' inci Yüzdelik & 50,6 & 46,3 & 18,9 & 47,1 & 1003,8 \\
\hline Medyan & 260,4 & 218 & 19,5 & 53,3 & 1008,1 \\
\hline 75' inci Yüzdelik & 459,6 & 491 & 22,2 & 58,5 & 1011,4 \\
\hline Max. & 650,9 & 672,4 & 26,3 & 63,3 & 1020,6 \\
\hline Skewness & 0,2 & 0,3 & 0,8 & $-0,5$ & 0 \\
\hline Kurtosis & $-1,5$ & $-1,5$ & $-0,5$ & $-5,6$ & 0,1 \\
\hline $\begin{array}{c}\text { Kolmogorov- } \\
\text { Smirnov Test Sig. }\end{array}$ & 0,04 & 0,06 & 0,01 & 0,60 & 0,90 \\
\hline Frekans Dağılımı & Log-normal & Normal & $\begin{array}{c}\text { Log- } \\
\text { normal }\end{array}$ & Normal & Normal \\
\hline
\end{tabular}

\subsection{Bina İçi Radon Kaynaklı Yıllık Etkin Doz Eşdeğeri Tahminleri}

UNSCEAR 2000'de rapor edilen Denklem 1 kullanılarak bina içi Rn-222 yllık etkin doz eşdeğerleri (YEDE) 4 istasyon için hesaplanmış ve sonuçlar Tablo 3.5'te verilmiştir.

UNSCEAR (2000) raporuna göre yıllık maruz kalınan radyasyon etkin doz değeri 2,4 mSv'dir [18]. Bu değer, solunan havadaki radon gazı ve vücuda alınan radyonüklitlerin neden olduğu içsel maruz kalma ile kozmik ışınlar, kozmojenik radyonüklitler ve karasal radyasyonun neden olduğu dışsal maruz kalma sonucu alınan toplam yıllık doz eşdeğeridir. Radon soluma ile içsel maruz kalma sonucu alınan etkin doz eşdeğeri ise ylllık $1,15 \mathrm{mSv}$ olarak verilmektedir [18]. Tablo 3.5'teki veriler bu referans değere göre değerlendirildiğinde çalışma saatleri için Amfi için hesaplanan hariç olmak üzere elde edilen sonuçlar radon soluma ile alınan etkin doz eşdeğerini (1,15 mSv) aşmamaktadır. Kütüphane hariç olmak üzere kafetarya, amfi derslik ve bilgisayar laboratuvarı için, tüm gün bina içerisinde bulunulma sonucu alınacak yıllık etkin doz hesaplamaları için elde edilen sonuçların UNSCEAR (2000) raporunda belirtilen radon soluma ile alınan etkin doz eşdeğerininin $(1,15 \mathrm{mSv})$ üzerinde bulunduğu görülmektedir [18].

Tablo 3.5. Bina İçi Rn-222 Kaynaklı Yıllık Etkin Doz Eşdeğeri Tahminleri

\begin{tabular}{|c|c|c|}
\hline Ölçüm Yeri & $\begin{array}{c}\text { Tüm gün için (24 saat) alınacak } \\
\text { yıllık etkin doz }\end{array}$ & $\begin{array}{c}\text { Çalışma saatleri için (8 saat) } \\
\text { alınacak yıllık etkin doz }\end{array}$ \\
\hline Kütüphane & $0,53 \mathrm{mSv}$ & $0,13 \mathrm{mSv}$ \\
\hline Kafeterya & $1,59 \mathrm{mSv}$ & $0,38 \mathrm{mSv}$ \\
\hline Amfi & $8,46 \mathrm{mSv}$ & $2,00 \mathrm{mSv}$ \\
\hline Laboratuvar & $3,83 \mathrm{mSv}$ & $0,91 \mathrm{mSv}$ \\
\hline
\end{tabular}




\subsection{Elektromanyetik Alan Ölçümleri}

Teknolojinin gelişmesiyle, bilgisayar, wireless, cep telefonları vb. cihazların sürekli kullanıldığı ofis ortamlarında çalışanlar için elektromanyetik alanın önemi oldukça büyüktür. Bununla birlikte, günümüzde sadece çalışma ortamlarında değil günlük yaşantımızda da elektromanyetik alana oldukça maruz kalıyoruz. $\mathrm{Bu}$ nedenle iyonize radyasyon kaynaklarından olan radon (Rn-222) konsantrasyonlarının belirlenmesinin yanı sıra iyonlaştırıcı olmayan elektromanyetik alan (EMA) radyasyonları şiddetlerinin ölçülmesi de Ege Üniversitesi öğrencileri ve personeli için büyük önem taşımaktadır.

Ege Üniversitesi içerisinde, elektromanyetik alan ölçümleri için, Merkez Kütüphane, bilgisayar laboratuvarı ve öğrenci kafeteryası olmak üzere 3 istasyon belirlenmiștir. Alınan elektromanyetik alan ölçümlerinin tanımlayıcı istatistikleri Tablo 3.6'da verildiği gibidir.
Tablo 3.6'da görüldüğü üzere, alınan ölçümlerde, en yüksek manyetik alan șiddeti Kütüphane Giriș Katı'nda ölçülmüștür. Bunun nedeni, Kütüphane'nin giriş katında öğrencilerin kullanması için konulmuş olan çok sayıdaki bilgisayara ve bu ortamdaki öğrenci yoğunluğunun çok olmasına bağlanabilir.

Elektronik Haberleșme Cihazlarından Kaynaklanan Elektromanyetik Alan Siddetinin Uluslararası Standartlara Göre Maruziyet Limit Değerlerinin Belirlenmesi, Kontrolü ve Denetimi Hakkında Yönetmelikte Değişiklik Yapılmasına Dair Yönetmelik'te (2011) elektromanyetik alan limit değerleri verilmiștir [21]. Bu çalıșma boyunca alınan EMA ölçüm sonuçlarının bu değerlerin çok altında kaldığı görülmektedir. Tablo 3.6.' de kütüphanede alınan EMA ölçüm sonuçları ve ICNIRP'nin $900 \mathrm{MHz}$ ve $1800 \mathrm{MHz}$ frekans değerleri için belirlemiş olduğu limit değerler sırasıyla $41,25 \mathrm{~V} / \mathrm{m}$ ve $58.33 \mathrm{~V} / \mathrm{m}$ şeklindedir [17].

Tablo 3.6. Seçilen istasyonlarda EMA ölçüm sonuçları için tanımlayıcı istatistik

\begin{tabular}{|c|c|c|c|c|c|c|}
\hline & $\begin{array}{c}\text { Bilgisayar } \\
\text { Lab. } \\
\text { (V/m) }\end{array}$ & $\begin{array}{c}\text { Kütüphane } \\
\text { Giriş Kat } \\
\text { (V/m) }\end{array}$ & $\begin{array}{c}\text { Kütüphane } \\
\text { 1. Kat } \\
(\mathrm{V} / \mathrm{m})\end{array}$ & $\begin{array}{c}\text { Kütüphane } \\
\text { 2.Kat } \\
(\mathrm{V} / \mathrm{m})\end{array}$ & $\begin{array}{c}\text { Öğrenci } \\
\text { Kafeteryası } \\
\text { İç }(\mathrm{V} / \mathrm{m})\end{array}$ & $\begin{array}{c}\text { Öğrenci } \\
\text { Kafeteryası } \\
\text { Dış (V/m) }\end{array}$ \\
\hline Ölçüm Sayısı & 96 & 84 & 96 & 96 & 96 & 96 \\
\hline $\begin{array}{c}\text { Aritmetik } \\
\text { Ortalama } \pm \\
\text { SH }\end{array}$ & $1,82 \pm 0,13$ & $1,85 \pm 0,16$ & $1,96 \pm 0,13$ & $1,74 \pm 0,12$ & $1,98 \pm 0,11$ & $1,75 \pm 0,12$ \\
\hline $\begin{array}{c}\text { Geometrik } \\
\text { Ortalama }\end{array}$ & 1,44 & 1,47 & 1,68 & 1,46 & 1,91 & 1,43 \\
\hline $\begin{array}{c}\text { Standart } \\
\text { Sapma (SD) }\end{array}$ & 0,13 & 0,16 & 0,13 & 0,12 & 0,11 & 0,12 \\
\hline Min. & 0,17 & 0,33 & 0,73 & 0,38 & 0,30 & 0,14 \\
\hline $\begin{array}{c}25 \text { ' inci } \\
\text { Yüzdelik }\end{array}$ & 0,92 & 0,98 & 1,15 & 0,98 & 1,35 & 0,99 \\
\hline Medyan & 1,36 & 1,51 & 1,52 & 1,38 & 1,79 & 1,44 \\
\hline $\begin{array}{c}75^{\prime} \text { inci } \\
\text { Yüzdelik }\end{array}$ & 2,25 & 2,14 & 2,19 & 1,95 & 2,47 & 2,11 \\
\hline Max. & 6,87 & 9,7 & 7,62 & 6,40 & 5,20 & 5,62 \\
\hline Skewness & 1,39 & 2,66 & 2,02 & 1,34 & 0,93 & 1,41 \\
\hline Kurtosis & 1,68 & 9,78 & 4,32 & 3,86 & 1,01 & 1,79 \\
\hline $\begin{array}{c}\text { Kolmogorov- } \\
\text { Smirnov } \\
\text { Test Sig. }\end{array}$ & 0,00 & 0,00 & 0,00 & 0,00 & 0,36 & 0,01 \\
\hline $\begin{array}{l}\text { Frekans } \\
\text { Dağılımı }\end{array}$ & Lognormal & Lognormal & Lognormal & Lognormal & Normal & Lognormal \\
\hline
\end{tabular}




\section{Tartışma ve Sonuç}

\section{Radon Gazı}

$\mathrm{Bu} 4$ istasyon için, Şekil 4.1'de ortalama Rn-222 ölçüm değerleri ve ICRP'ye göre Rn konsantrasyon limit değeri ile birlikte gösterilmiștir.

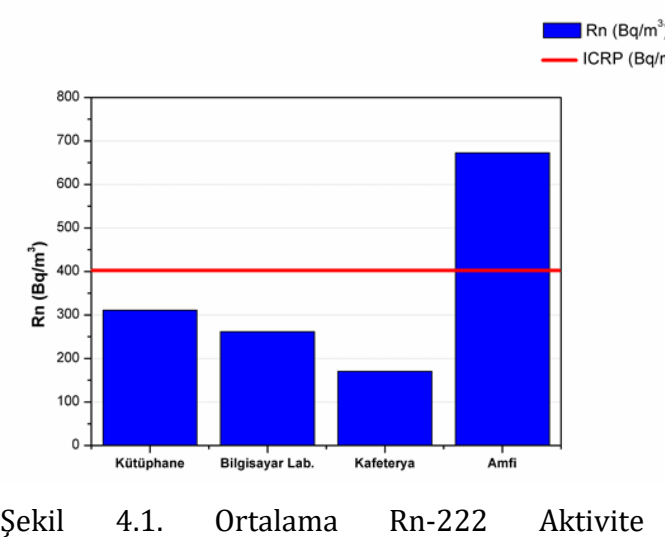

Konsantrasyonu Seviyeleri (Bq/ $\mathrm{m}^{3}$ )

Ülkemizde kapalı ortamlarda (ofis, ev vb.) Rn gazı konsantrasyon limit değeri, ICRP'nin belirlemiş olduğu limit değer olan $400 \mathrm{~Bq} / \mathrm{m}^{3}$ olarak kabul edilmektedir.

Buna göre, Șekil 4.1'de amfi derslikte ölçülen maksimum Rn konsantrasyon seviyesinin bu değerin çok üzerinde olduğu görülmektedir. Merkez Kütüphane, bilgisayar laboratuvarı ve öğrenci kafeteryasındaki Rn-222 ölçüm sonuçlarının maksimum değerleri ise, bu limit değerin altında kalmaktadır. Bunun nedenleri olarak, dersliğin zemin katta ve yerin altına doğru inen bir amfi olması, bulunduğu binanın çok eski olmasından dolayı zemin çatlaklarının bulunması, yıl içerisinde diğer dersliklere göre daha az kullanılması nedeniyle hava sirkülasyonunun az olması söylenebilir. Literatürde yer alan çalışmalarda, kapalı ortamlardaki radon konsantrasyon seviyelerinin mevsimsel olarak, bina yapısına ve havalandırma sistemi vb. faktörlere bağlı olduğu vurgulanmaktadır [22].

Avrupa ülkeleri, ICRP ve Türkiye, radon konsantrasyon limit değerini $400 \mathrm{~Bq} / \mathrm{m}^{3}$ olarak kabul ederken, Dünya Sağlık Örgütü (WHO) radon konsantrasyon limit değerini $100 \mathrm{~Bq} / \mathrm{m}^{3}$ olarak belirlemiştir [23]. Dünya Sağlık Örgütü'nün (WHO) limit değerine göre ölçülen maksimum değerler değerlendirildiğinde ise 4 istasyona ait ortalama ölçüm değerlerinin bu limit değeri aştığı görülmektedir.

Alınan Rn-222 ölçüm sonuçlarının, istasyonların konumu ve ne sıklıkta havalandırıldıkları göz önüne alındığında, bu faktörlerle ne derece değişiklik gösterdiği görülmektedir. Buna örnek olarak, çok sık kullanılmayan amfide ölçülen maksimum değerlerin, limit değerlerin çok üzerinde olması fakat gün içerisinde sık sık havalanmakta olan öğrenci kafeteryasının maksimum ölçüm değerlerinin limit değerin oldukça altında kalması verilebilir. Aynı zamanda radon gazı konsantrasyonları sıcaklık, nem ve basınca bağlı olarak da değişim göstermektedir. Șekil 2.1'de örnek olarak verilen sıcaklık, nem ve basınç değişimlerine bakıldığında, bilgisayar laboratuvarındaki Mart ayl Rn-222 ölçüm sonuçlarında radon konsantrasyonlarının sıcaklığın düşüş gösterdiği, nem oranında ise az da olsa bir azalma görüldüğü durumlarda pik yaptığı görülmektedir.

Doğal bir radyasyon kaynağı olan radona maruz kalmamak mümkün değildir. Fakat maruziyet seviyesini olabildiğince aza indirmek insan sağlı̆̆ için önemlidir. Bina içi radon konsantrasyon seviyesini en aza indirmek için alınabilecek önlemler TAEK tarafından ortaya konulmuş ve aşağıda listelenmiştir [24].

-Bina yapımlarında, yapı malzemelerinin radyoaktivite ölçümleri yapılarak, tavsiye edilen seviyelerdeki yapı malzemeleri ve binaların toprakla temasını engelleyecek izolasyon malzemeleri kullanılmalıdır.

-Su ve doğalgaz sistemleri kontrol altında olmalıdır.

-Havalandırma sistemleri, kapalı binalardaki radon konsantrasyon seviyesini düşürebilecek kapasitede olmalıdır.

-Eski binalarda, çatlak ve kırıklardan dolayı radon konsantrasyon seviyeleri yeni binalara göre daha yüksektir. Bu nedenle, bu kırık ve çatlakların onarılması gerekmektedir.

-Radon gazl, akciğer kanserinin en önemli ikinci nedenidir ve bu konuda önlem almak gerekmektedir. Yukarıda verilen önlemlerin yanında, Türkiye'de radon gazının ve etkilerinin bilinmemesi nedeniyle özellikle kapalı ortamlarda çalışanlara radon gazı ve insan sağlı̆̆ı üzerindeki etkileri hakkında eğitim verilmesi zorunlu hale getirilmelidir. 


\section{Elektromanyetik Alan}

Günümüzde sadece çalıșma ortamlarında değil günlük yaşantımızda da elektromanyetik alana sık sık maruz kalındığı göz önüne alındığında, teknolojinin gelişmesiyle, bilgisayar, wireless, cep telefonları vb. cihazların sürekli kullanıldığı ofis ortamlarında çalıșanlar için elektromanyetik alanın öneminin ne kadar büyük olacağı dikkat çekicidir.

Yapılan pek çok çalışmada, elektromanyetik alanın olumsuz etkilerinden bahsedilmiştir. $\mathrm{Bu}$ çalışmalar, elektromanyetik alanın göze etkisi, endokrin sisteme etkisi, dolaşım sistemine etkisi, üreme sistemine etkisi, DNA yapısına etkisi, sinir sistemine etkisi, biyolojik etkileri ve elektromanyetik alanın kanserle ilişkisi olmak üzere pek çok alanda değişiklik göstermektedir [25].

Sarıkahya (2014) tarafından tamamlanan uzmanlık tezi çalışmasında, elektromanyetik alan sınır değerleri belirlenirken, elektromanyetik alan şiddeti seviyesinin, vücut sıcaklığını $1^{\circ} \mathrm{C}$ arttırdığı durumda zararlı düzeyde olduğunun kabul edilmesi gerektiği vurgulanmıştır. Sınır değerler pek çok ülkede farklı referanslara göre belirlenirken, Türkiye' de ICNIRP'nin belirlemiş olduğu elektromanyetik alan sınır değerleri kabul edilmektedir [25]. Elektronik Haberleșme Cihazlarından Kaynaklanan Elektromanyetik Alan Șiddetinin Uluslararası Standartlara Göre Maruziyet Sınır Değerlerinin Belirlenmesi, Kontrolü ve Denetimi Hakkında Yönetmelikte Değișiklik Yapılmasına Dair Yönetmelik'te (2011) bu sınır değerler verilmiștir (Elektronik Haberleșme Cihazlarından Kaynaklanan Elektromanyetik Alan Șiddetinin Uluslararası Standartlara Göre Maruziyet Sınır Değerlerinin Belirlenmesi, Kontrolü ve Denetimi Hakkında Yönetmelikte Değișiklik Yapılmasına Dair Yönetmelik, 2011). Bu çalışmada alınan EMA ölçüm sonuçlarının bu değerlerin çok altında kaldığı görülmektedir. ICNIRP'nin $900 \mathrm{MHz}$ ve $1800 \mathrm{MHz}$ frekans değerleri için belirlemiș olduğu sınır değerler sırasıyla $41,25 \mathrm{~V} / \mathrm{m}$ ve $58.33 \mathrm{~V} / \mathrm{m}^{\prime} \operatorname{dir}[17]$.

Bu bağlamda çalıșma süresince Kütüphane giriș, Kütüphane 1. kat, Kütüphane 2. kat, bilgisayar laboratuvarı, öğrenci kafeteryası (İç) ve öğrenci kafeteryası (Dış)'nda alınan ölçümlerin bu sınır değerlerin çok altında olduğu Şekil 4.2'de görülmektedir.
İstasyonlarda alınan ölçümlerin ICNIRP'nin belirlediği limit değerlerin çok altında olması olumlu bir sonuç olarak düşünülebilir. Yine de elektromanyetik alana uzun vadede maruz kalındığı durumda insan sağlığına olan etkileri göz ardı edilemez.

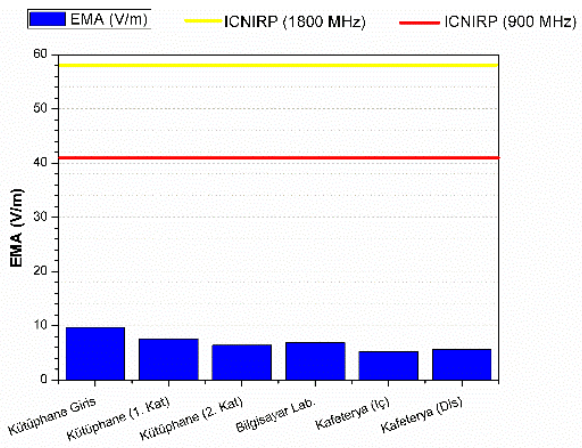

Şekil 4.2. Maksimum elektromanyetik alan şiddeti seviyeleri $(\mathrm{V} / \mathrm{m})$.

Elektromanyetik alanın çok ciddi sağlık etkilerinin olmasının yanında, düşük seviyede maruz kalınsa bile, uzun sürelerde maruz kalındığı durumda insan üzerinde baş ağrısı, baş dönmesi, halsizlik, yorgunluk vb. geçici fakat olumsuz sağlık etkileri de bulunmaktadır. Bu nedenle bu çalışmada alınan EMA ölçüm sonuçları sınır değerlerin çok altında çıkmış olsa bile her zaman önlem alınmalıdır.

Elektromanyetik alan şiddetine maruziyeti azaltmak adına aşağıda verilen öneriler dikkate alınmalıdır:

- Kullanılmayan elektrikli cihazlar ya kapalı tutulmalı ya da fișten çekilmelidir.

- Masaüstü bilgisayar kullanılıyorsa, düşük radyasyonlu bilgisayar ekranı tercih edilmeli veya ekran filtresi kullanılmalıdır.

- Dizüstü bilgisayarlar prize takılı olmadığı durumda (șarj edilmiș șekilde) daha az elektromanyetik alan yaymaktadır. Şarj ederken uzak durmaya özen gösterilmelidir.

- Her işyerinin elektromanyetik alan şiddeti ölçümleri yapılmalıdır. Sınır değerlerin üzerinde radyasyon seviyesindeki yerler için önlem alınmalıdır.

İş hayatında elektrikli cihazlardan uzak durmak mümkün olmasa da önlem almak gerekmektedir. Bazı kişilerin elektromanyetik alana hassasiyeti daha fazladır ve bu kișilerde belli başlı reaksiyonlar görülebilir. $\mathrm{Bu}$ reaksiyonlar, yorgunluk, halsizlik, gözde rahatsızlıklar, baş 


\section{DEÜ FMD 23(68), 357-367, 2021}

ağrısı vb. türdendir. Fakat uzun vadede elektromanyetik alanın daha ciddi sağlık sorunlarına neden olduğu bilinmektedir. Bu nedenle, çalışanlar elektromanyetik alanın sağlık üzerine etkileri hakkında bilinçlendirilmelidir.

\section{Teșekkür}

Bu çalışmanın gerçekleştirilmesinde 17FBE010 no.lu proje ile destek sağlayan Ege Üniversitesi Bilimsel Araştırma Projeleri (BAP) birimine katkılarından dolayı teșekkür ederiz.

\section{Kaynakça}

[1] Özbay, T. ve Karadeniz, Ö., 2016, Indoor Radon Measurement in İzmir Province, Turkey, International Journal of Environmental Analytical Chemistry, 96:8, 752 762, DOI: 10.1080/03067319.2016.1196684.

[2] Şen et al., 2013. Effect of natural gas usage on indoor radon levels, J Radioanal Nucl Chem (2013) 295:277-282.

[3] Uzbey, S. ve Çelebi, N., Çorum İlinde Radon Gazı Ölçümü, 10. Ulusal Nükleer Bilimler ve Teknolojileri Kongresi, 235-244s, (2009).

[4] George, A.C., 2008, World History Of Radon Research And Measurement From The Early 1900's To Today, American Institude of Physics, 1034, 20-33s. doi: 10.1063/1.2991210.

[5] Olszewski, J., Chruścielewski, W., and Jankowski, J., 2005, Radon on underground tourist routes in Poland, International Congress Series, ScienceDirect, Vol. 1276, February 2005, 360-361s.

[6] Cömlek, Ü., Tınaztepe Mağarası' nın Radon Seviyesinin Araştırılması, Yüksek Lisans Tezi, Selçuk Üniversitesi Fen Bilimleri Enstitüsü, (2010).

[7] Alkan and Karadeniz, 2014. Indoor (222)Rn Levels and Effective Dose Estimation of Academic Staff in IzmirTurkey, Biomedical and Environmental Sciences (2014) 27 (4), 259-267s.

[8] Karadeniz et al. 2016. Preliminary dose estimation from indoor radon for the medical staff of Radiation Oncology and Nuclear Medicine (2016) 22(7), 1574-1582. [9] Yarar et al., 2014. Indoor radon levels of spas and dwellings located around Bayındır geothermal region, J Radioanal Nucl Chem (2014) 299:343-349s.

[10] Zeydan, Z.E., Zeydan, Ö. ve Yıldırım, Y., 2009, Hasta Bina Sendromu, 9.Ulusal Tesisat Mühendisliği Kongresi, 587-595s.

[11] TAEK, Kapalı Ortamlarda Radon Gazı, Teknik Rapor, $(2012 / 3)$.

[12] ICRP, 2018, Summary of ICRP Recommendations on Radon, UK.

[13] Pișkin, A., 2016, Ofis Çalıșanlarının Radon Gazı Maruziyetinin Nükleer İz Dedektör Yöntemine Göre Belirlenmesi ve Sağlık Üzerine Etkileri, Çalışma ve Sosyal Güvenlik Bakanlığı, Ankara.

[14] Radyasyon Güvenliği Yönetmeliği, 2000, Resmi Gazete Sayısı: 23999.

[15] Türkkan, A. ve Pala, K., Cok Düșük Frekansl Elektromanyetik Radyasyon ve Sağlı Etkileri, Uludağ Üniversitesi Mühendislik-Mimarlık Fakültesi Dergisi, Sayı: 2, 11-22s, (2009).
[16] Yakıncı, Z.D., Elektromanyetik Alanın İnsan Sağlığı Üzerindeki Etkileri, İnönü Üniversitesi Sağlık Hizmetleri Meslek Yüksekokulu Dergisi, Cilt:4, Sayı: 8, (2016).

[17] Elhasoğlu, D., Elektromanyetik Kirliliğin Zararlı Etkileri, Yüksek Lisans Tezi, Çukurova Üniversitesi Fen Bilimleri Enstitüsü, (2006).

[18] UNSCEAR, Exposures from Natural Radiation Sources, United Nations Scientific Committee on the Effects of Atomic Radiation, United Nations, New York, (2000).

[19] C. Öztürk, B., Çam, N.F., Yaprak, G., (2013) Reference levels of natural radioactivity and $137 \mathrm{Cs}$ in and around the surface soils of Kestanbol pluton in Ezine region of Çanakkale province, Turkey, Journal of Environmental Science and Health, Part A, 48:12, 1522-1532, DOI: $10.1080 / 10934529.2013 .797242$.

[20] Karadeniz, Ö., Akal, C., (2014), Radiological mapping in the granodiorite area of Bergama (Pergamon)-Kozak, Turkey, Journal of Radioanalytical and Nuclear Chemistry, DOI: $10.1007 / \mathrm{s} 10967-014-3216-9$.

[21] Elektronik Haberleşme Cihazlarından Kaynaklanan Elektromanyetik Alan Siddetinin Uluslararası Standartlara Göre Maruziyet Limit Değerlerinin Belirlenmesi, Kontrolü ve Denetimi Hakkında Yönetmelikte Değișiklik Yapılmasına Dair Yönetmelik, Resmi Gazete Sayısı: 30394, (2018).

[22] Güler, C. Ve Cobanoğlu, Z., Radon Kirliliği, Cevre Sağlığı Temel Kaynak Dizisi, No:44, T.C. Sağlık Bakanlığı, (1997).

[23] Ozan, S.S. ve Ekinci, C.E., Yapllarda Radon Fenomeni ve Radon-Sağlık İlișkisi, NWSA Engineering Sciences, 1590-1602s, (2011)

[24](http://www.taek.gov.tr/ogrenci/bolum4_02.html). [25] Sarıkahya, N.M., 2014, Bir İş Yerinde Elektromanyetik Alan Ölçümü Yapılması ve Sonuçlarının İş Sağlığı ve Güvenliği Yönünden Değerlendirilmesi, Çalıșma ve Sosyal Güvenlik Bakanlığı, Ankara. 